\title{
The Types of Communication Accommodation Strategies in English as Foreign Language (EFL) Classrooms
}

\section{Ida Bagus Manuaba ${ }^{*}$, I Nyoman Adi Jaya Putra²}

1,2 English Language Education, Post Graduate Program, Universitas Pendidikan Ganesha, Singaraja, Indonesia

A R T I C L E I N F O

Article history:

Received 18 December

2020

Received in revised

Form 06 January 2021

Accepted 1 February 2021

Available online 09

February 2021

Keywords:

Communication

Accommodation

Strategies, EFL

Classrooms

\begin{abstract}
A B S T R A C T
English is one of international language which is taught widely in various countries in the world. Entering millennial and industrial 4.0 era, English has important role as the function of English is as a tool or media to communicate with other countries and it is also as language of science, technology, social-economy, culture, and art. Communication Accommodation Theory which consists of communication accommodation strategies are very important to accommodate the students in teaching learning activity. This research aimed at analyses types of communication accommodation strategies are used by teacher when teaching Basic English and the motive of implementing communication accommodation strategies by the teacher Classroom Interactions. Subjects of this research were two the English teachers. This research was designed in qualitative research. The data were collected through voice recorder, interview and documentation. The data were analyzed qualitatively. The results of this study revealed that there were four strategies used in teaching learning process by the teacher such as approximation, interpretability, discourse management and emotional expression. Moreover, the teachers had some main motive to apply these strategies such as to make the students understand, give clear explanation to students and get the students' attention.
\end{abstract}

\section{Introduction}

English is one of international language which is taught widely in various countries in the world (Gilakjani \& Ahmadi, 2011; Teng, 2012; Weizheng, 2019). Entering millennial and industrial 4.0 era, English has important role as the function of English is as a tool or media to communicate with other countries and it is also as language of science, technology, social-economy, culture, and art (Buasuwan, 2018; Dadan, 2019; Dong, 2020; Mwalongo, 2016; Pan \& Wu, 2013). As an international language, English is very important to be learnt. It is showed by the research of (Estliden, 2017) that from 60 students who were given question about "is it important to learn English?", all of them answered that learning English is very important because English is an international language and an important tool when it is used to communicate in various situations with people from other countries. The importance of learning English is also felt in Indonesia (Cakrawati, 2017; Ningsih, 2016).

In Indonesia, English is taught in formal and non-formal education. Formal Education is a structured and tiered education covering primary education, secondary education and university and nonformal education is an education which is outside of formal education being able to be implemented structurally and gradually (PP RI No 32 Tahun 2013, 2013). English in Indonesia is a foreign language. Teaching English as a foreign language need great effort. The factor of achievement in learning English comes from personal and environment factors. Teaching English to students which English is not their mother language is not easy. Six basic principles in language teaching such as systematic approach, predictable and friendly environment, motivation, interaction (accommodation and modification), clear interaction and review (Fjortfoft et al., 2014; Heidari, 2020; Wilson, 2016). The six principles are dedicated to teacher who is expected to have a good pedagogical qualification in teaching, educating, guiding and facilitating students. This competency facilitates the teacher and students in gaining the purpose of learning such as student are able to convey messages, share information and interact with other by using communication. 
Communication can be defined in many ways. In simple terms communication is information transmitted, a verbal or nonverbal message and a process by which information is exchanged between individuals through a common system of symbols, signs, or behaviour (Giles \& Gallois, 2015; Rosenbaum, 2005; Weizheng, 2019). People deliver their idea and information through communication. In communication, language plays an important role, event by using mother language or foreign language, such as in Indonesia English is and foreign language. Communication cannot run smoothly if the people do not have a good language skill and communication skill (Akın et al., 2015; Nguyen \& Terry, 2017; Ning, 2011). People cannot accommodate their communication if the people cannot adjust their language.

In order to avoid communication breakdown, people accommodate their language to their communication partner. People adjust their language and communication patterns to those of others. Communication breakdown occurs when people fail to understand others' feelings using contextual cues specific to others. This situation not only occurs on social or community interaction but also in teaching learning interaction especially in communicating using English as a foreign language. The types of communication strategies used by the students in EFL classrooms (Dewi et al., 2018). The study indicated that numerous types of strategies were used by the students when communicating in the classroom for instance, the use of fillers, self-repetition, code switching, appeal for help, self- repair, asking for confirmation, massage abandonment, omission, approximation, and literal translation.

However, learning English as foreign language (EFL) becomes a big problem for learners who have limited ability in English. It is not only problem for the learner but also for the teacher. This case also occurs on hospitality school, which has various educational background students. Maintain an effective communication between teacher and students become hard, especially when the teacher introduces hospitality terminology to the students during teaching learning process. Communication strategies to EFL students are really needed in order to maintain an effective communication between teacher and students, it based on a study which were conducted by (Teng, 2012). Based on the research, there are significant different for the college students who received the instruction of communication strategy. The significance such as higher communicative effectiveness in the post test, improved oral communication proficiency test score, encouraging EFL students to engage in interactional activity and communication strategy pedagogically affective for students. The study focusses on the communication strategy used by teacher for college students in general not the used of communication accommodation strategy. It found essential to analyze the communicate.

A few study of communication accommodation strategy conducted on ELT classes. The study was conducted to know the motives of the teacher in applying communication accommodation strategy in ELT class (Cakrawati, 2017; Weizheng, 2019). This study showed that teacher used more convergence features in accommodative strategies rather than divergence. Besides, teacher's motives in applying communication accommodation strategies were to emphasize the closeness with students and to improve students' understanding in classroom interaction. Meanwhile other research found that more accommodation strategies used by the teachers make better the interaction in the classroom. It means that by applying accommodation strategy could boost an effective interaction in the teaching learning process.

Based on the previous research, it focused on the communication strategy, only a few of them focus on communication accommodation strategy in ELT. The previous research concerning on how the communication accommodation strategies applied in different cultural background and language. Those study focus on the form of how convergence and divergence worked. It not could be found yet the study about teachers' communication accommodation strategy which is consists of approximation, interpretability, discourse management, emotional expression and interpersonal control in vocational school, especially tourism vocational school. Furthermore, the study of communication accommodation strategy could not be found in Indonesian classroom interaction.

Program Studi di Luar Domisili (PDD) Jembrana is the only one Diploma 1 tourism vocational school in Jembrana which is under Politeknik Negeri Bali's order. This school is designed as a preparation for entablising Akademi Komunitas Negeri Jembrana. So, in the first five years of this school would be proofed whether this school suitable or not to be established. It means in order to gain the target, all of the components in this school should be operated maximaly, especially in teaching leraning process. Besides, when the researcher conducted a preliminary observation, the students in this school have limited ability in English and lack of hospitality knowledge. Most of the students in this school do not come from hospitality vocational school, most of them from other vocational school such as automotive, nursery, farming and Senior High School.

This phenomenon becomes significant considerations of the researcher to find out (i) the implementation of communication accommodation strategies used by the teacher in learning Basic English and (ii) the motive of implementing communication accommodation strategies by the teacher in 
PDD Jembrana, in order to analyse kind of communication strategy used in teaching learning process to create an effective communication and gain the teaching goal.

\section{Methods}

This research aimed at analyses types of communication accommodation strategies are used by teacher when teaching Basic English and the motive of implementing communication accommodation strategies by the teacher Classroom Interactions. This study was a descriptive qualitative research (Sugiyono, 2014). This study was conducted at Program Studi Diluar Domisili (PDD) Jembrana Politeknik Negeri Bali. The participants were EFL teachers in hospitality vocational school in the first semester.

This research was focus on the communication accommodation strategy used by English teacher of hospitality vocational school in Program Studi Diluar Domisili (PDD) Jembrana - Politeknik Negeri Bali. The subjects of this study were two English teachers in hospitality vocational school in the first semester. The objects of this study were (1) types of communication accommodation strategies used by teacher in PDD Jembrana when teaching Basic English and (2) the motive of implementing communication accommodation strategies by the teacher in PDD Jembrana Classroom Interactions.

The data collection processes took several steps, they were, lesson plans implementation by teachers, unobtrusive observation of lesson implementations by observer, recordings teachers' communication strategies, and data processing in table formats. The obtained data were analyzed qualitatively with the theory from (Giles \& Gallois, 2015).

\section{Result and Discussion}

\section{Results}

The findings of the study show that there were 15 dimensions which were used by the English teacher. From the total number of the dimensions showed that teacher 1 used fourteen dimensions of the strategies meanwhile teacher 2 use eleven dimensions of the strategies. Both teacher 1 and teacher 2 used approximation strategy by adjusting pitch, tone and rate in teaching learning process. The result show that the teacher adjusting their pitch tones and rate when they wanted to build engagement and rapport with students. Meanwhile, there were 1 interpretability strategy was used by teacher 1 namely use other word to express same meaning, teacher 2 used 2 interpretability strategy such as use high frequency words and expression and use other word to express same meaning. The result show that teacher 1 and teacher 2 use same strategy during teaching and learning process. The same strategy use by the English teachers was used other word to express same meaning. They did it because they wanted to give a deep understanding about the word and expression they said to the students.

Discourse management was the third strategy which was used by teacher 2 and teacher 2 . In discourse management strategies there were 7 same strategy used by the teachers. The strategy was repetition, turn taking, topic control, asking referential question, conversational repair or self-repair, feedback and delay or extending waiting time. Repetition was saying words or expression regularly or resaying the interlocutor words or expression. The two English teachers did it to make the students knew what the teacher said clearly. Turn taking is a type of organization in discourse management where participants take turn in their speaking. The result showed that both teachers applied this strategy in order to give chance to the students to speak. Topic control also played an important role in teaching learning process. Topic control is used to control unnecessary interruption during teaching learning process, this strategy was used by the teachers to make the students focus on the topic discussed. Asking referential question was asking question in order to seeking information that the interlocutors could understand what the locator said. This strategy was done to make sure the students could catch what the teacher explained clearly and checked the students' understanding. It was done by asking some question related to topic discussed. Conversational repair or self-repair was making self-correction in our speech. Both teachers know that they were made mistakes and immediately repair it to give right example and information to students. Feedback is return information of a result and process. In teaching learning process teacher 1 and teacher 2 gave feedback to student by commenting and correcting the students. It was done to evaluate the students in doing a process. The last strategy in discourse management used by English teacher was delay or waiting extended time. Delay or waiting extended time is time gaining to fill pauses; it was done by the teacher by saying filler word. The result showed that the teacher applied it because the teacher need time to think to continue the communication.

The last communication strategy used by the teacher was emotional expression. This strategy consists of showing appreciation, warmth, sharing happiness, pro-sociality and other positive emotional 
expressions. In this case, teacher 1 and teacher 2 applied sharing happiness by making some joke in teaching learning process. The result showed that the strategy used by the teacher because they wanted to make a good and relax atmosphere in the classroom.

\section{Discussion}

Based on the result of type of communication accommodation strategies used by English teacher in teaching learning process the most frequently used was asking referential question which is a part of discourse management strategy. The reason of using referential question was checking the students understanding and reconfirm whether the students could follow the topic or not. Moreover the result was different from the study which comes from (Teng, 2012; Weizheng, 2019; Wu, 2020). The study was about teacher and students' interaction in EFL classroom in a university in central China. It was found that interpretability was the most frequently strategy which is used by the teacher.

In order to find out the motive of using communication accommodation strategy by English teacher, the researcher used the theory from (Giles \& Gallois, 2015). The researcher used interview to find out the motive based on the interview guide. The interview guide consists 15 questions that should be answered by both teachers. In using approximation strategy which were indicated by adjusting pitch, tone and rate, the motive of teacher 1 used that strategy because the teacher wanted to get the students' attention and made them focus to the topic given, besides teacher 2 used this strategy because he wanted to cover all of the students, the teacher made sure all of the students could hear his voice.

Interpretability was the second strategy used by the teacher. This strategy consists of using high frequency word and expression and used other words to express same meaning. Based on the communication documentation observation, only teacher 3 used high frequency word and expression, beside both teachers used other word to express same meaning. Teacher 1 used the strategy by translating the word or expression into Indonesian language, it was done to make clear understanding of a word or expression given, the same reason also showed by teacher 2. Based on the interview, teacher 1 state that the motive of using high frequency word or expression because the teacher wanted to make the students understand of the word and expression and made the students easy to remember the words. Thus, the motive of teacher 2 used the strategy because he wanted to make the word familiar to the students. Moreover, teacher 1 and teacher 2 have the same motive in using other word to express some meaning. Because they taught in hospitality school, they had to introduce some hospitality terminology, in order to make the students understand to the topic discussed, the teachers used this strategy. This strategy also applied to give clear explanation to the students.

The third finding was the used of discourse management. In this strategy, the teacher used repetition, praise, turn taking, topic control, asking referential question, conversational repair or selfrepair, back channelling, feedback and using non-verbal signal. The motive of teacher 1 and teacher 2 used repetition was to make the students understand and familiar with the expressions. Repetition occurred not only when the teacher explained something but when the student spoke, both teachers sometime repeat some students' words. The motive of teacher $1 \mathrm{did}$ it to reconfirm what the student said and teacher 2 did the same strategy to make sure he got the message from the students. Turn taking is the next strategy used in teaching learning process, the motive of teacher 1 did this strategy to get the student's attention in teaching learning process and make the students focus to the lesson, this strategy was done by giving the students chance to speak. It could be done randomly or in order. The other motive for teacher 2 was to give an equal chance to all of the students in speaking. In order to check and reconfirm the students' understanding, asking referential question strategy was applied. The motive of the teacher did this strategy to make sure that the student understands and could follow the explanation of the teachers. Based on the documentation observation, both teachers did some mistake especially grammatical error. To overcome the problem, the teacher handled the problem by applying conversational repair or self-repair. The motive of applying this strategy was to give true information to the students and avoid misunderstanding between the teachers and students. Moreover, teacher 1 and teacher 2 did delay in their communication. The strategy occurred when the teacher forgets what they should say, it was applied by saying some filler word. The motive of teacher 1 and teacher 2 applied this strategy because the teacher took time to think what they should say.

Furthermore, emotional expression was the strategy used by both teachers, the teacher showed their emotional expression mostly by sharing happiness by making some joke. Teacher 1 and teacher 2 did this strategy very often, the motive of applying this strategy was to make a good atmosphere in the class so the students could relax and focus to the lesson. It was student's involvement when joke was applied in the classroom and the application of joke element is commendable inside the classroom (Ahmad et al., 2018; Ajabshir, 2018; Albirini, 2006). In order to accommodate all of the students, the 
teacher involved an equality relationship between teacher and all students by giving equal attention to every single student.

The motive of using communication accommodation strategy both teacher 1 and teacher 2 had same reason in some strategy. In order to create good atmosphere and encourage the students to involve in the teaching activities, English teachers try to adjust themselves to boost effective interaction.

A few study of communication accommodation strategy conducted on ELT classes. The study was conducted to know the motives of the teacher in applying communication accommodation strategy in ELT class (Cakrawati, 2017; Eslami et al., 2014; Interlanguage \& Ross, 1988; Weizheng, 2019). This study showed that teacher used more convergence features in accommodative strategies rather than divergence. Besides, teacher's motives in applying communication accommodation strategies were to emphasize the closeness with students and to improve students' understanding in classroom interaction. Meanwhile other research found that more accommodation strategies used by the teachers make better the interaction in the classroom (Weizheng, 2019; Yazdanpanah, 2012). It means that by applying accommodation strategy could boost an effective interaction in the teaching learning process.

Based on the previous research, it focused on the communication strategy, only a few of them focus on communication accommodation strategy in ELT. The previous research concerning on how the communication accommodation strategies applied in different cultural background and language. Those study focus on the form of how convergence and divergence worked. It not could be found yet the study about teachers' communication accommodation strategy which is consists of approximation, interpretability, discourse management, emotional expression and interpersonal control in vocational school, especially tourism vocational school. Furthermore, the study of communication accommodation strategy could not be found in Indonesian classroom interaction.

Based on the finding of the study, there were suggestions that could be present as communication accommodation theory which is consist of communication strategies in teaching learning process is a strategy to accommodate the students to involve themselves in learning process, the researcher suggest that the teacher could use the strategy in order to make a good teaching learning activity. The researcher hopes this research will be a reference for the future study on the use of communication accommodation theory.

\section{Conclusion}

The teachers used four strategies in teaching learning process. The strategies were approximation, interpretability, discourse management and emotional expression. There were fifteen dimensions of the strategy namely adjusting pitch, tone and rate, use high frequency word and expression, repetition, praise, turn taking, topic control, asking referential question, conversional repair or self-repair, back channelling, feedback, delay (extending waiting time), appreciation, sharing happiness, and prosociality expression. teacher 1 who teach in Front Office class use fourteen dimensions of the strategies namely adjusting pitch, tone and rate, repetition, praise, turn taking, topic control, asking referential question, conversional repair or self-repair, back channelling, feedback, delay (extending waiting time), appreciation, sharing happiness, and pro-sociality expression. Furthermore, teachers 2 who teach in Housekeeping class use eleven dimensions of the strategies namely adjusting pitch, tone and rate, use high frequency word and expression, repetition, praise, turn taking, topic control, asking referential question, conversional repair or self-repair, feedback, delay (extending waiting time), and sharing happiness. Based on the finding of the study, there were suggestions that could be present as ccommunication accommodation theory which is consist of communication strategies in teaching learning process is a strategy to accommodate the students to involve themselves in learning process, the researcher suggest that the teacher could use the strategy in order to make a good teaching learning activity. The researcher hopes this research will be a reference for the future study on the use of communication accommodation theory.

\section{References}

Ahmad, N. A., Mohamed, S., Hasnan, K. A., Ali, N., \& Ahmad Puad, F. N. (2018). The Use of Teacher's Joke Increases Students' Involvement inside Classroom. The International Journal of Social Sciences and Humanities Invention, 5(10), 5039-5046. https://doi.org/10.18535/ijsshi/v5i10.06.

Ajabshir, Z. F. (2018). The effect of synchronous and asynchronous computer-mediated communication (CMC) on EFL learners' pragmatic competence. Computers in Human Behavior, Cmc. https://doi.org/10.1016/j.chb.2018.11.015. 
Akın, F., Koray, Ö., \& Tavukçu, K. (2015). How Effective is Critical Reading in the Understanding of Scientific Texts? Procedia - Social and Behavioral Sciences, 174, 2444-2451. https://doi.org/10.1016/j.sbspro.2015.01.915.

Albirini, A. (2006). Teachers Õ attitudes toward information and communication technologies: the case of Syrian EFL teachers. 47, 373-398. https://doi.org/10.1016/j.compedu.2004.10.013.

Buasuwan, P. (2018). Rethinking thai higher education for thailand 4.0. Asian Education and Development Studies, 7(2), 157-173. https://doi.org/10.1108/AEDS-07-2017-0072.

Cakrawati, L. M. (2017). Students' Perceptions on the Use of Online Learning Platforms in Efl Classroom. English Language Teaching and Technology Journal (ELT-Tech Journal, 1(1), 22-30.

Dadan. (2019). Revolusi Industri 4.0.

Dewi, N. L. T., Batan, G., \& Myartawan, I. P. N. W. (2018). Types Of Communication Strategies Used By Young Learners In Efl Classrooms. Lingua Scientia, 25(2), 53-61.

Dong, M. (2020). Structural relationship between learners' perceptions of a test, learning practices, and learning outcomes: A study on the washback mechanism of a high-stakes test. Studies in Educational Evaluation, 64(October 2018), 100824. https://doi.org/10.1016/j.stueduc.2019.100824.

Eslami, Z. R., Mirzaei, A., \& Dini, S. (2014). The role of asynchronous computer mediated communication in the instruction and development of EFL learners ' pragmatic competence. System, 1-13. https://doi.org/10.1016/j.system.2014.09.008.

Estliden, K. P. (2017). Why is it important to learn English?: A study of attitudes and motivation towards English and English language learning in Swedish upper secondary school. Avdelningen for Humaniora.

Fjortfoft, A., McLaughlin, T., Derby, M., Everson, M., \& Johnson, K. (2014). The effects of two direct instruction teaching procedures to basic skills to two students with disabilities. Multidisciplinary Journal of Educational Research, 4(2), 151-181. https://doi.org/10.4471/remie.2014.09.

Gilakjani, A. P., \& Ahmadi, M. R. (2011). A Study of Factors Affecting EFL Learners ' English Listening Comprehension and the Strategies for Improvement. Journal of Language Teaching and Research, 2(5), 977-988. https://doi.org/10.4304/jltr.2.5.977-988.

Giles, H., \& Gallois, C. (2015). Communication Accommodation Theory". The International Encyclopedia of Language and Social Interaction. In I. John Wiley \& Sons (Ed.), The International Encyclopedia of Language and Social Interaction (First). John Wiley \& Sons, Inc. https://doi.org/10.4324/9781410614308.

Heidari, K. (2020). Critical thinking and EFL learners' performance on textually-explicit, textually-implicit, and script-based reading items. Thinking Skills and Creativity, 37(August), 100703. https://doi.org/10.1016/j.tsc.2020.100703.

Interlanguage, I. N., \& Ross, S. (1988). Kobe University of Commerce, Tarumi, Japan. 16(3), 347-354.

Mwalongo, L. J. (2016). Learning Through English Language in Early Childhood Education : A Case of English Medium Schools in China. Journal of Education and Practice, 7(28), 28-35.

Nguyen, H., \& Terry, D. R. (2017). English Learning Strategies among EFL Learners: A Narrative Approach. Journal of Language Learning, 3(1), 4-19.

Ning, H. (2011). Adapting cooperative learning in tertiary E LT. ELT Journal Volume, 65(1), 60-70. https://doi.org/10.1093/elt/ccq021.

Ningsih, S. (2016). Guided Writing to Improve the Students ' Writing Ability of Junior High School Students. EFL Journal, 1(2), 129-140.

Pan, C., \& Wu, H. (2013). The Cooperative Learning Effects on English Reading Comprehension and Learning Motivation of EFL Freshmen. English Language Teaching, 6(5), 13-27. https://doi.org/10.5539/elt.v6n5p13.

$\begin{array}{llllllll}\text { PP RI No } 32 \text { Tahun 2013, } 2 & \text { Sekretariat } & \text { Negara } & 148 & \text { (2013). }\end{array}$ https://doi.org/10.1017/CB09781107415324.004. 
Rosenbaum, T. (2005). Effective Communication Skills for Highway and Public Works Officials. Cornell Local Roads Program.

Sugiyono. (2014). Metode Penelitian Pendidikan Pendekatan Kuantitatif, Kualitatif, dan R\&D. Alfabeta.

Teng, H.-C. (2012). A Study on the Teach Ability of EFL Communication Strategies. Procedia - Social and Behavioral Sciences, 46(1987), 3566-3570. https://doi.org/10.1016/j.sbspro.2012.06.106.

Weizheng, Z. (2019). Teacher-Student Interaction in EFL Classroom in China: Communication Accommodation Theory Perspective. English Language Teaching, 12(12), 99. https://doi.org/10.5539/elt.v12n12p99.

Wilson, K. (2016). Critical reading, critical thinking: Delicate scaffolding in English for Academic Purposes (EAP). Thinking Skills and Creativity, 22, 256-265. https://doi.org/10.1016/j.tsc.2016.10.002.

Wu, Z. (2020). Journal of Second Language Writing Tracing EFL writers ' digital literacy practices in asynchronous communication: A multiple-case study. Journal of Second Language Writing, 50(September 2019), 100754. https://doi.org/10.1016/j.jslw.2020.100754.

Yazdanpanah, Z. (2012). The effect of explicit teaching of story structure on EFL learners ' use of communication strategy. 32(Iccs 2011), 391-398. https://doi.org/10.1016/j.sbspro.2012.01.059. 